\title{
Shear Behaviour of Continuous Tapered Steel Plate Girders with Corrugated Webs
}

\author{
Mohamed A. Dabaon, Ahmed M. El-Hadidy, Rashad M. Manaa \\ Structural Engineering Department, \\ Faculty of Engineering, Tanta University
}

\begin{abstract}
During previous years, so many attempts have been made to reduce the own weight of the steel members used in bridges, as well as reducing the cost of construction. One of these attempts is to use tapered (i.e. non-prismatic with varying depth) steel plate girders with corrugated webs (TPGCWS). The corrugated steel plates are widely used as structural elements in A. many structural applications because of their numerous $B$. favourable properties compared with traditional flat plates. $C$ Moreover, they have been used due to their aesthetical appearance, especially in the case of TPGCWs. So many researches have been made to investigate the shear behaviour of $E$. TPGCWS for the case of simple girder, to the author's F. knowledge, no one has investigated the shear behaviour of $G$. TPGCWS for the case of continuous girder. So, the aim of this $H$. paper is to investigate the shear behaviour of TPGCWS for the case of continuous girder. Two experimental models have been ${ }^{\mathrm{I}}$ tested to verify the finite element (FE) analysis and compare the $\mathrm{J}$. experimental results with $F E$ results and the existing design $K$. equations.
\end{abstract}

Keywords: Tapered girder, Corrugated webs, Shear M. buckling, Interactive buckling and Finite element analysis. $N$.

$$
\text { I. INTRODUCTION }
$$

Plate girders with corrugated webs (PGCWS) were used in $\mathrm{Q}$. many engineering applications due to their high resistances. $\mathrm{R}$. The use of corrugated webs to increase the out of plane stiffness and buckling strength without using vertical or horizontal stiffeners has been considered for a very long time; first in aircraft design and later for civil engineering applications in building and bridges [1].

Plate girders may be classified into two main types according to the shape of the corrugated web. The first one is the prismatic plate girders with corrugated webs (PPGCWS) which are used in many bridges from many years ago [1], while the second type is the tapered plate girders with corrugated webs (TPGCWS) that have recently been utilised. TPGCWS are characterized by their structure efficiency and aesthetical appearance. Additionally, their tapered shape with gradually varying inertia allows for more effective stress distribution inside the web panel. This reduces the weight of used steel and therefore the overall cost of the structure decreases.

\section{A. Corrugation configuration and geometric notations}

Corrugation configuration and geometric notation for different types of corrugated webs; trapezoidal, curved and triangular, are shown in Fig. (1). Where, $c$ represents the inclined fold width; $b$ is the flat panel width; $t_{w}$ is the web thickness; $d$ is the horizontal projection of the inclined fold width; $h_{r}$ is the corrugation depth; $\alpha$ is the corrugation angle; $s$ is one corrugation wave length; $q$ is the horizontal projection of one corrugation wave length.

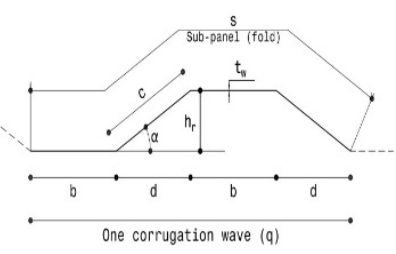

(a) Trapezoidal

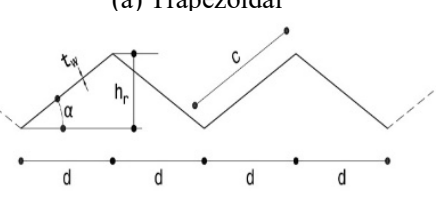

(b) Triangular profile

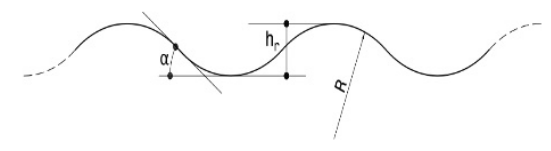

(c) Curved profile

Figure 1. Corrugation configuration and geometric notation.

\section{B. Straining actions on PPGCWS}

The corrugated steel plate does not resist axial forces and bending moments but has high resistance to shear buckling as shown in Fig. (2). It was assumed, in steel girders with corrugated webs, that the web purely carries shear forces due to the accordion effect [2-4]. Corrugated webs do not carry significant longitudinal stresses from the primary flexure of the girders and, consequently, the bending moment was reasonably assumed to be carried totally by the flanges. It is worth pointing out for the same reason, that the shear strength can be determined without consideration of moment-shear interaction. Accordingly, the shear stress $(\tau)$ of the web can be assumed constant and, hence, can be calculated by $\tau=$ $\frac{V}{t_{w} h_{w}}$; where $V$ is the applied shear, while $t_{w}$ and $h_{w}$ are the thickness and the height of the web, respectively.
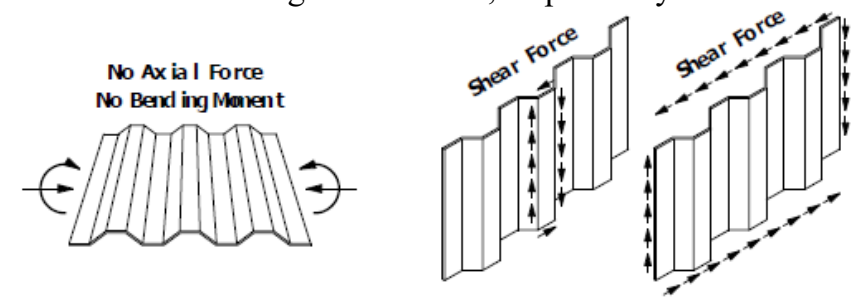

.Figure 2. Properties of corrugated steel web plate [5]. 
On the other hand, according to Figs. (3) and (4), the corrugated steel plates are quite beneficial for the webs of prestressed concrete bridges for the efficiency of the capacity for both of the prestressed tendons and the shear force. In construction, formworks, reinforcement, and other site operations are not required since the construction of concrete webs can be neglected. As a result, the construction work on site can be reduced. In addition, the environmental impact can be reduced in accordance with the reduction of formworks. Furthermore, only upper and lower concrete slabs are considered on resisting the axial forces and bending moments as shown in Fig. (3).

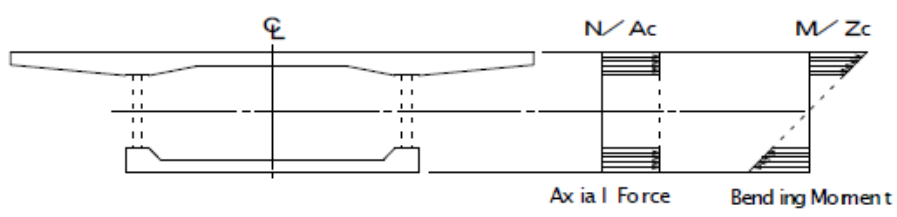

Figure 3. Effective cross section for axial force and bending moment [5].

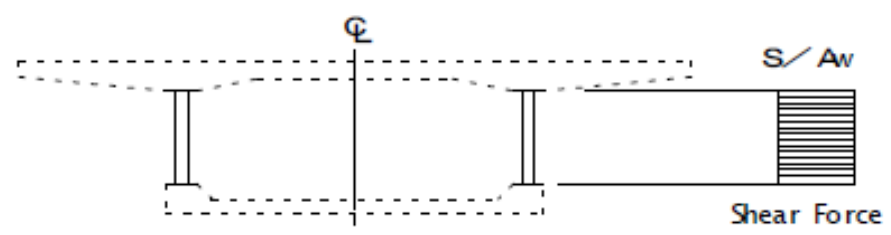

Figure 4. Effective cross section for shear force [5].

Based on many experiments and analyses, the assumption that plane sections remain plane was verified and the similar ultimate flexural moment between corrugated web bridges and conventional prestressed concrete bridge was also verified $[6,7]$. Therefore, apart from ignoring the stiffness of corrugated steel webs, the design for bending moments and axial forces is the same as the conventional prestressed concrete bridges [8]. As shown in Fig. (4), the shear forces are resisted by the corrugated steel webs. Based on the experiments and analysis carried out to date, it has been confirmed that the applied shear forces are mostly resisted by the corrugated steel webs [7]. Therefore, the shear forces are designed by assuming that all applied shear forces are resisted by the corrugated steel webs as shown in Fig. (4), which is certainly on the safe side [8].

\section{Elastic shear buckling stress}

For steel plate girders with long or unstiffened web panels, the web shear strength is a critical limit state because they generally have slender webs. However, for corrugated webs there are three elastic shear buckling modes that control their behaviour (local, global and interactive shear buckling stresses) as shown in Fig. (5).

\section{Local shear buckling stress}

This mode of buckling occurs when a flat-panel between vertical edges has a large width to thickness ratio (Slenderness of the individual folds of the web $\left.\left(w / t_{w}\right)\right)[3,9,10]$ where $w$ is the maximum fold width. Local buckling mode is controlled by deformations within a single flat panel of the web as shown in Fig. (5-b).

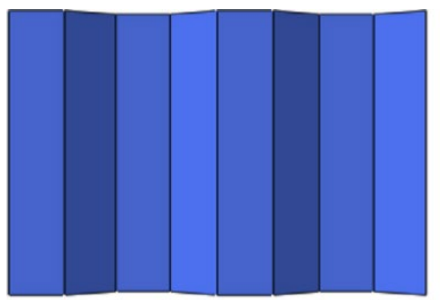

(a) Elevation of corrugated webs

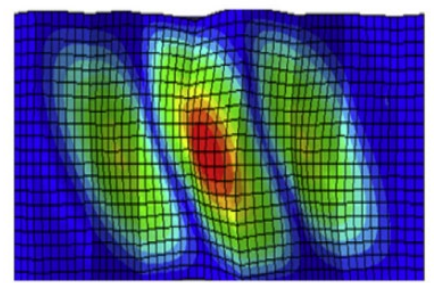

(c) Global buckling

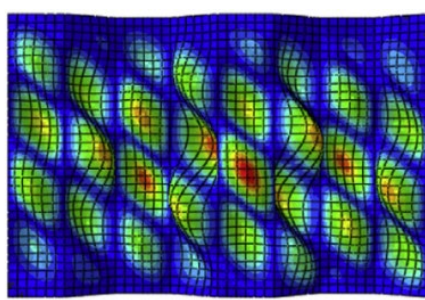

(b) Local buckling

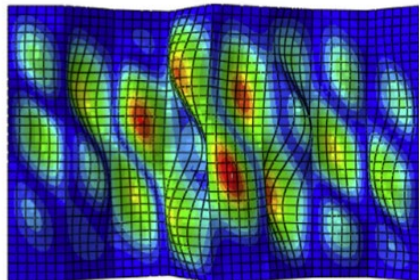

(d) Interactive buckling
Figure 5. Different buckling shapes in prismatic corrugated webs: (a) elevation of the corrugated web, (b) local buckling, (c) global buckling and (d) interactive buckling.

Plate theory can be used to predict the local shear buckling stress of corrugated webs based on research results [11-13]. A given fold (longitudinal or inclined) is assumed to be supported by the flanges along its horizontal edges and by adjacent folds along its vertical edges. The elastic local shear buckling stress of the corrugated webs $\left(\tau_{c r, L}\right)$ can be determined by Eq. (1)

$$
\tau_{c r, L}=K_{L} \frac{\pi^{2} E}{12\left(1-v^{2}\right)}\left(\frac{t_{w}}{w}\right)^{2}
$$

where $E$ and $v$ are the elastic modulus and the Poisson's ratio of the material, respectively, $w$ is the maximum fold width (maximum of the longitudinal fold width $b$ and the inclined fold width $c$ ) and $t_{w}$ is the web thickness as shown in Fig. (1a). $K_{L}$ is the local shear buckling coefficient that depends upon the boundary conditions and the fold aspect ratio. A small aspect ratio $\left(w / h_{w}\right)$ where $h_{w}$ is the web depth minimizes $K_{L}$ and in this case $K_{L}$ lies between 5.34 (assuming the fold has simply supported edges) and 8.98 (assuming the upper and lower edges to be fixed).

\section{Global shear buckling stress}

For the case of dense corrugation, global buckling controls the buckling mode. This buckling mode involves multiple panels and extends diagonally over the entire depth $[3,9,10]$ similar to a flat plate web as in Fig. (5-c). The calculation of the global elastic buckling stress $\left(\tau_{c r, G}\right)$ has been initiated by Easley [14] for the corrugated webs as given in Eq. (2).

$$
\tau_{c r, G}=K_{G} \frac{D_{x}{ }^{0.25} D_{y}{ }^{0.75}}{t_{w} h_{w}{ }^{2}}
$$

where $D_{x}$ is the transverse bending stiffness per unit length of the corrugated web, $D_{y}$ is the longitudinal bending stiffness per unit length of the corrugated web and $I_{y}$ are defined as:

$$
\begin{aligned}
& D_{x}=\frac{q}{s} \cdot \frac{E t_{w}{ }^{3}}{12} \\
& D_{y}=\frac{E I_{y}}{q}
\end{aligned}
$$


purely carries shear forces due to the accordion effect [2-4]. For that reason, the flanges were maintained constant in the experimental program.

Both specimens had the same inclined fold width $(c=$ $100 \mathrm{~mm}$ ) and the same longitudinal fold width $(b=$ $100 \mathrm{~mm})$. The corrugation depth $\left(h_{r}\right)$ was $50 \mathrm{~mm}$ as shown in Fig. (7). Moreover, Table (2) shows the geometric parameters of corrugation configuration. Each specimen consists of two panels, the left one is a corrugated web panel of thickness $(2 \mathrm{~mm})$, the right one is a stiffened flat web panel ${ }_{500}$ of thickness $(6 \mathrm{~mm})$ so that failure occurs at the corrugated web panel. The web height differs in each specimen from $\left(h_{w o}\right)$ and increasing at the middle to $\left(h_{w 1}\right)$ as shown in Fig. (8).

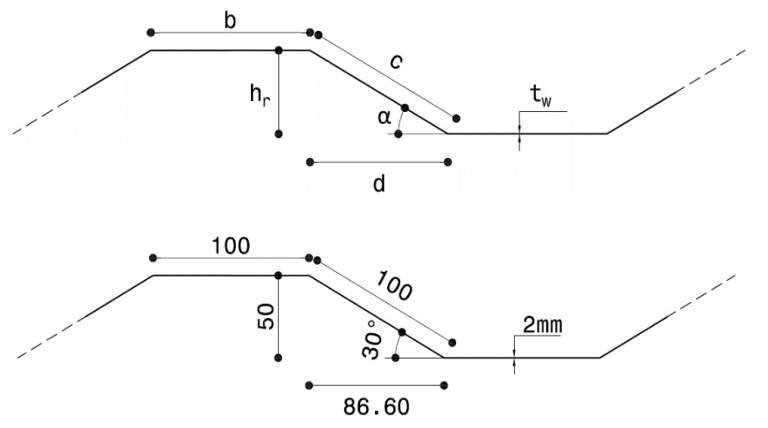

Figure 7. Corrugated profile of the specimens.

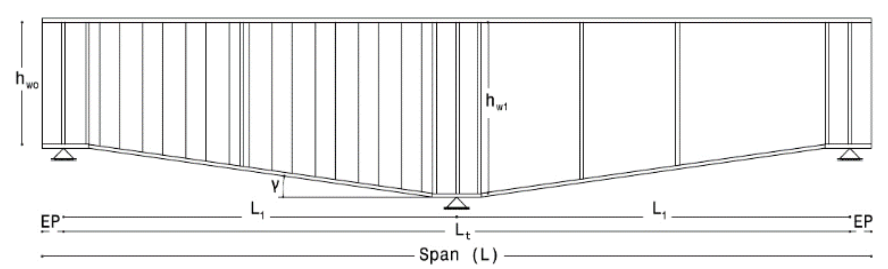

Figure 8. Geometric parameters of girder.

TABLE 2

GEOMETRIC PARAMETERS OF CORRUGATION CONFIGURATION

\begin{tabular}{|c||c|c|c|c|c|c||}
\hline \multirow{2}{*}{$\begin{array}{c}\text { Corrugation } \\
\text { profile }\end{array}$} & $\begin{array}{c}c \\
{[\mathrm{~mm}]}\end{array}$ & $\begin{array}{c}b \\
{[\mathrm{~mm}]}\end{array}$ & $\begin{array}{c}h_{r} \\
{[\mathrm{~mm}]}\end{array}$ & $\begin{array}{c}\mathrm{d} \\
{[\mathrm{mm}]}\end{array}$ & $\begin{array}{c}\alpha \\
{[\circ]}\end{array}$ & $\begin{array}{c}t_{w} \\
{[\mathrm{~mm}]}\end{array}$ \\
\cline { 2 - 7 } & 100 & 100 & 50 & 86.60 & 30 & 2 \\
\hline
\end{tabular}

In order to prevent the web bearing failure due to concentrated loads, bearing stiffeners with $15 \mathrm{~mm}$ thickness were attached under the concentrated loads and at each support. In addition, one more stiffener was used at the right flat panel in order to prevent the failure at the flat panel. Each test specimen contains flat web plates, of $6 \mathrm{~mm}$ thickness, at the middle of the girder, where three double-sided stiffeners were used. This is illustrated in Figs. (9) and (10). As can be seen, a non-rigid end post $(E P)$ with an extension of $100 \mathrm{~mm}$ and web thickness of $6 \mathrm{~mm}$ was used at each end for the entire tests.

The specimens were labelled such that the $h_{w 0}$ and the $h_{w 1}$ could be identified from the label. The label format used is $G-h_{w 0}-h_{w 1}$. For instance, the label G-500-700 represents the plate girder with $h_{w o}=500 \mathrm{~mm}$ and $h_{w 1}=700 \mathrm{~mm}$. However, after the fabrication of the specimens, the actual dimensions of all specimens were measured exactly. Table (3) shows the actual dimension for the specimens.

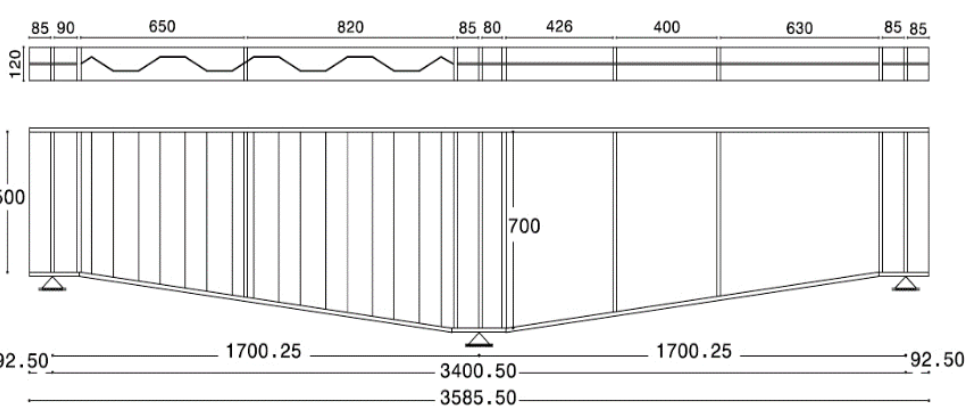

Figure 9. Geometric details of specimen (G1-500-700).

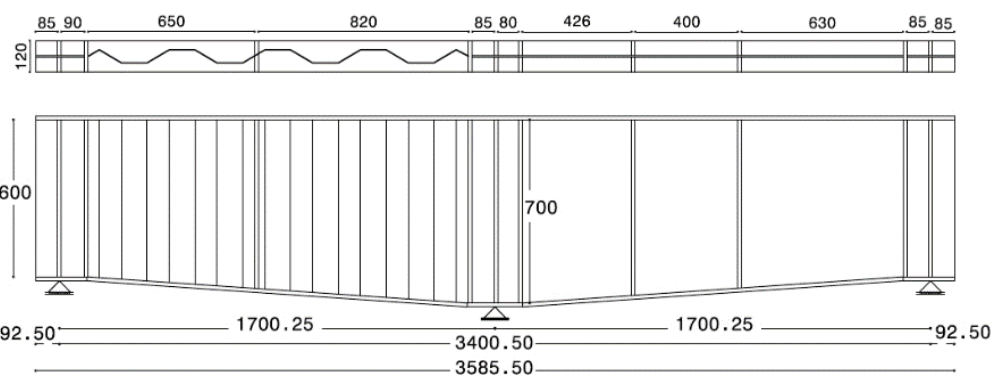

Figure 10. Geometric details of specimen (G2-600-700).

TABLE 3

GEOMETRICAL DETAILS OF THE TEST SPECIMENS

\begin{tabular}{||c||c||c|c|c|c|c|c||}
\hline No. & $\begin{array}{c}\text { Designati } \\
\text { on }\end{array}$ & $\mathrm{L} 1$ & $\begin{array}{c}\text { Span } \\
(\mathrm{L}) \\
{[\mathrm{mm}]}\end{array}$ & $\begin{array}{c}\text { End post } \\
(\mathrm{EP}) \\
{[\mathrm{mm}]}\end{array}$ & $h_{w 0}$ & $h_{w 1}$ & $\gamma$ \\
{$[\mathrm{mm}]$} & {$[\mathrm{mm}]$} & {$[0]$} \\
\hline \hline (G.1) & $\begin{array}{c}\text { G1-500- } \\
700\end{array}$ & 1700.25 & 3585.5 & 92.50 & 500 & 700 & 8 \\
\hline \hline (G.2) & $\begin{array}{c}\text { G2-600- } \\
700\end{array}$ & 1700.25 & 3585.5 & 92.50 & 600 & 700 & 4 \\
\hline
\end{tabular}

\section{B. Description of test set-up}

Two concentrated loads were applied using a rigid loading beam of size IPN400 of steel grade St 52 as shown in Fig. (11). Hinged condition was applied at mid span, roller end conditions were applied at the right and left ends of the specimen as shown in Fig. (12).

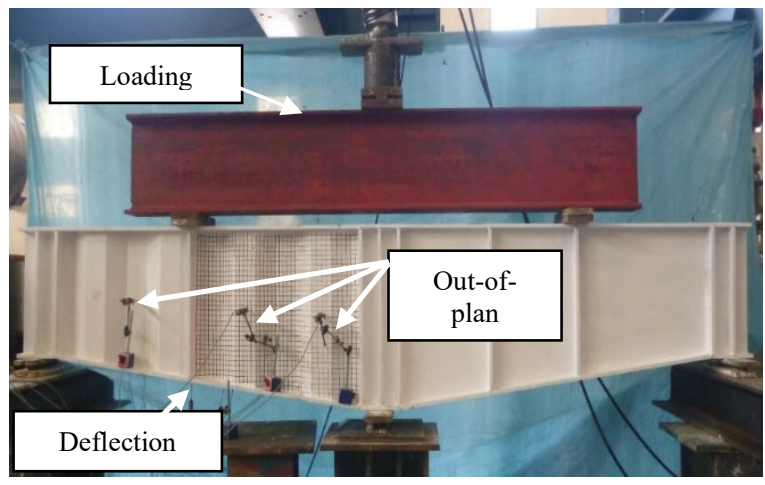

Figure 11. Test setup for specimen G1-500- 


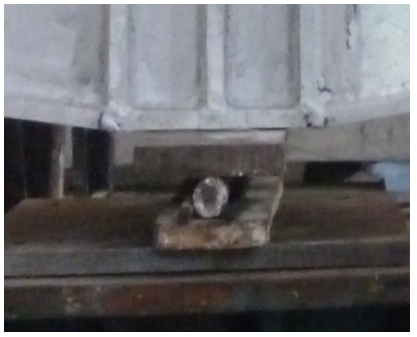

(a) Hinged support

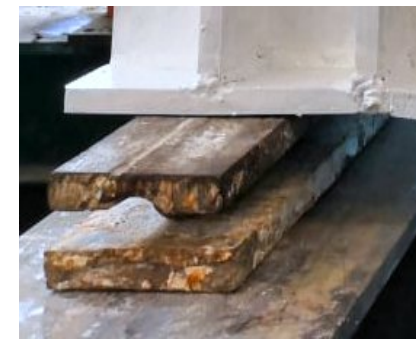

(b) Roller support
Figure 12. End conditions used in the tests.

Strain gauges were used to measure the axial strain of each specimen. Three strains were used to measure the vertical strain at the middle of three different folds. Moreover, three additional strains were used to measure the horizontal strain. Four LVDTs were used, one to measure the vertical deflection of each girder under the applied load $(\delta 1)$ and three more were set perpendicular to critical panel folds, which were chosen according to the classification of typologies as shown in Fig. $(8)$, to measure the out-of-plan displacement $(\delta 2, \delta 3$, and $\delta 4)$ at the middle of three critical folds.

\section{Loading procedure}

Each specimen was painted using white wash which was used as an indicator for the pattern of failure. The white wash was allowed to dry prior to drawing the grid at the folds of corrugated web panel which can be seen for instance in Fig. (11). The specimen was then ready to be placed in the test frame. A small load was applied to the specimen at the beginning to eliminate any gap that might exist between any of the test components. After that, the strain gauges and the LVDTs were positioned and set to zero before loading started. The loading procedure was carried out in accordance with EC3 [25].

The concentrated load was applied to the specimens in increments of about $5 \mathrm{kN}$ up to $30 \%$ of the expected design load and then unloaded. After this stage, the load was applied by small load increments until the end of the test. A data acquisition system was used to record the load and the readings of strains and the LVDTs at regular intervals during the tests. Then the specimen was removed and carefully examined after the test.

From the material tests, it was found that elastic modulus $E$ of used steel equal to $200.00 \mathrm{MPa}$, and Poisson's ratio, $v$, equal to 0.3 . The yield and ultimate stresses are given in Table (4).

TABLE 4

MEASURED MATERIAL PROPERTIES OF STEEL

\begin{tabular}{|c|c|c|}
\hline $\begin{array}{c}\text { Plate } \\
\text { thickness } \\
(\mathrm{mm})\end{array}$ & $\begin{array}{c}\text { Yield stress } \\
\left(F_{y}\right) \\
\mathrm{N} / \mathrm{mm}^{2}\end{array}$ & $\begin{array}{c}\text { Ultimate stress }\left(F_{u}\right) \\
\mathrm{N} / \mathrm{mm}^{2}\end{array}$ \\
\hline \hline 2 & 245.9 & 274.38 \\
\hline 6 & 256.4 & 315.62 \\
\hline 15 & 358.2 & 485.6 \\
\hline
\end{tabular}

\section{Test results}

The deformed shapes of specimen G1-500-700 are shown in Figs. (13), while the load-deflection curve $(\delta 1)$ is shown in Fig. (14). The ultimate load was $536.56 \mathrm{kN}$. The deflection value $\delta 1$ at the ultimate load was $9.39 \mathrm{~mm}$.

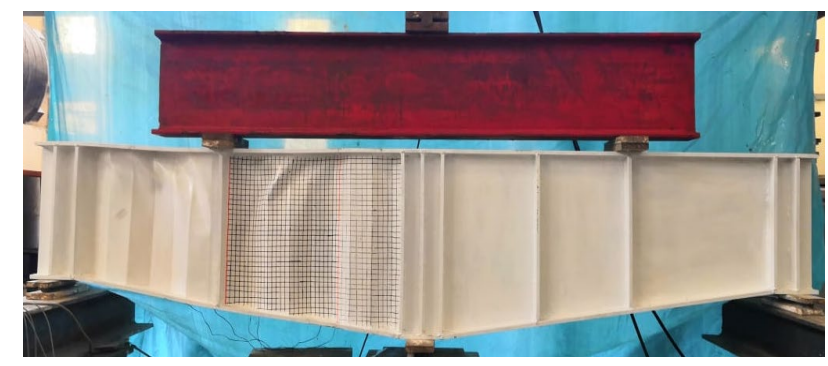

Figure 13. Deformed shape of specimen (G1-500-700) after testing.

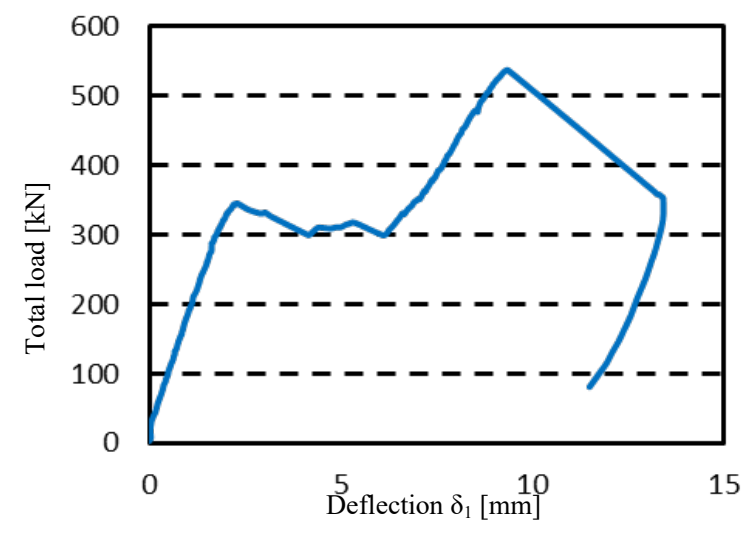

Figure 14. Load-deflection curve for specimen (G1-500-700).

The deformed shapes of specimen G2-600-700 are shown in Figs. (15), while the load-deflection curve $(\delta 1)$ is shown in Fig. (16). The ultimate load was $567.7 \mathrm{kN}$. The deflection value $\delta 1$ at the ultimate load was $17.88 \mathrm{~mm}$.

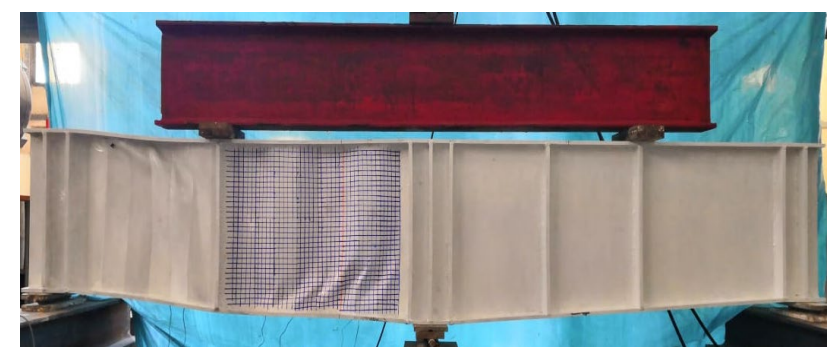

Figure 15. Deformed shape of specimen (G1-600-700) after testing.

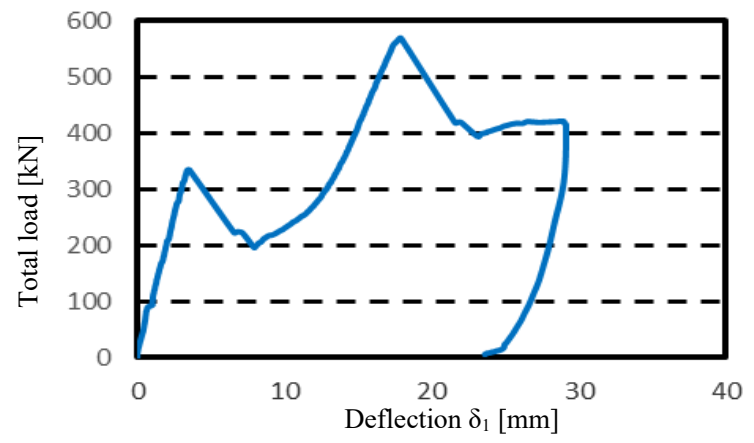

Figure 16. Load-deflection curve for specimen (G2-600-700). 
Values of ultimate and critical loads are given in Table (5). Also, the values of critical and ultimate shear stresses are given in Table (6).

TABLE 5

EXPERIMENTAL RESULTS FOR ALL SPECIMENS

\begin{tabular}{|c|c|c|c|c|c|c|c|}
\hline \multirow{2}{*}{$\begin{array}{l}\text { Specime } \\
\text { n }\end{array}$} & \multirow{2}{*}{$\begin{array}{l}\text { Ultim } \\
\text { at-e } \\
\text { load } \\
{[\mathrm{kN}]}\end{array}$} & \multirow{2}{*}{$\begin{array}{c}\text { Critic } \\
\text { a-1 } \\
\text { load } \\
{[\mathrm{kN}]}\end{array}$} & \multirow{2}{*}{$\begin{array}{c}\text { Deflec- } \\
\text { tion at } \\
\text { ultimate } \\
\text { load } \\
\delta 1 \\
{[\mathrm{~mm}]} \\
\end{array}$} & \multicolumn{3}{|c|}{$\begin{array}{c}\text { Out of plane } \\
\text { displacement [mm] }\end{array}$} & \multirow{2}{*}{$\begin{array}{l}\text { Mode } \\
\text { of } \\
\text { failure }\end{array}$} \\
\hline & & & & $\delta 2$ & $\delta 3$ & $\delta 4$ & \\
\hline $\begin{array}{l}\text { G1-500- } \\
\quad 700\end{array}$ & $\begin{array}{c}536.5 \\
6\end{array}$ & $\begin{array}{c}524.1 \\
2\end{array}$ & 9.39 & 5.42 & 3.57 & 0.04 & $\begin{array}{c}\text { Intera } \\
\text { ct-ive } \\
\text { buckli } \\
\text { ng }\end{array}$ \\
\hline $\begin{array}{l}\text { G2-600- } \\
\quad 700\end{array}$ & 567.7 & $\begin{array}{c}332.8 \\
1\end{array}$ & 17.88 & 14.6 & 1.66 & 1.39 & $\begin{array}{c}\text { Intera } \\
\text { ct-ive } \\
\text { buckli } \\
\text { ng }\end{array}$ \\
\hline
\end{tabular}

TABLE 6

ULTIMATE AND CRITICAL SHEAR STRESSES FOR ALL SPECIMENS

\begin{tabular}{|c|c|c|c||}
\hline SPECIMEN & $\begin{array}{c}\tau_{\text {exp }, u} \\
{\left[\mathrm{~N} / \mathrm{MM}^{2}\right]}\end{array}$ & $\begin{array}{c}\tau_{\text {exp, }, r} \\
{\left[\mathrm{~N} / \mathrm{MM}^{2}\right]}\end{array}$ & $\begin{array}{c}\tau_{y} \\
{\left[\mathrm{~N} / \mathrm{MM}^{2}\right]}\end{array}$ \\
\hline \hline G1-500-700 & 126.3 & 123.4 & 141.97 \\
\hline G2-600-700 & 122.9 & 68.7 & 141.97 \\
\hline
\end{tabular}

\section{CONCLUSION}

By reviewing the previous results, it can be noticed that the continuous TPGCWs strength of the specimens with $h_{w 0}=$ $500 \mathrm{~mm}$ is higher than that with $h_{w 0}=600 \mathrm{~mm}$. Figure (17) shows that the strength increased by about $5.48 \%$

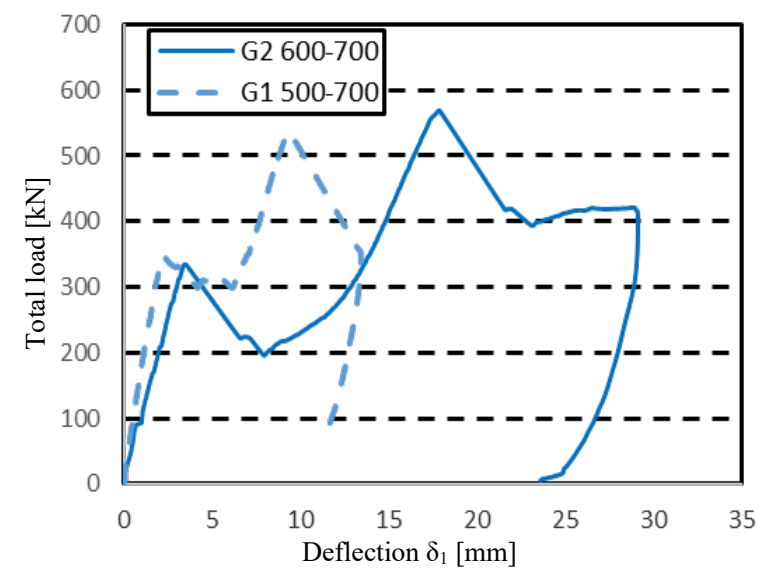

Figure 17. Load-deflection curve for both specimens,

\section{ACKNOWLEDGEMENTS}

This research was supported by Reinforced concrete and heavy structures laboratory at faculty of engineering, Tanta University.

\section{REFERENCES}

Sause, R., "Corrugated Web Girder Fabrication" ATLSS Reports, Paper 32,2003.

[2] Hamilton, R.W., "Behavior of Welded Girder with Corrugated Webs", Ph.D. thesis, University of Maine, 1993.
Driver, RG., Abbas HH., Sause R., "Shear Behavior of Corrugated Web Bridge Girders", Journal of Structural Engineering, ASCE, Vol. 132(2), pp. 195-203, 2006.

[4] Jian-Guo Nie, Li Zhu, Mu-Xuan Tao and Liang Tang, "Shear Strength of Trapezoidal Corrugated Steel Webs" Journal of Constructional Steel Research, Vol. 85, pp. 105-115, 2013.

Co Concrete Bridges with Corrugated Steel Web Construction", 30th Conference on Our World in Concrete \& Structures: 23-24 August, Singapore, 2005

[6] Yamaguchi, K., Yamaguchi, T. and Ikeda, S., "The Mechanical Behavior of Composite Prestressed Concrete Girders with Corrugated Steel Webs", Concrete Research and Technology, Vol. 8, No.1, Japan Concrete Institute, pp. 27-40, 1997.

[7] Mizuguchi, K., Ashiduka, K., Yoda, T., Sato, K., Sakurada, M. an Hidaka, S., "Loading Tests of the Hondani Bridge, Bridge and Foundation Engineering", Vol. 32, No. 10, Kensetsu-Tosho, Japan, pp. 25-34, 1998.

[8] Society for Research on Composite Structures with Corrugated Steel Web (Japan): Proposed Planning Manual for Composite Prestressed Concrete Bridges with Corrugated Steel Webs, 12, 1998.

[9] Moon, J., Yi, J., Choi, B.H. and Lee, H., "Shear Strength and Design of Trapezoidally Corrugated Steel Webs", Journal of Constructional Steel Research, Vol. 65, pp. 1198-1205, 2009.

[10] Sharp, M.L., Clark, J.W., "Thin Aluminium Shear Webs", J. Struct. Div. ASCE 97, ST4, PP. 1198-1205, 2009.

[11] Timoshenko, S.P. and Gere, J.M. "Theory of Elastic Stability", 2nd edition, NY, McGraw-Hill Publishing Co., 1961.

[12] Bulson, P.S., "Stability of Flat Plates", Elsevier, New York, 1970

[13] Galambos, T.V. (ed.), "Guide to Stability Design Criteria for Metal Structures", John Wiley \& Sons, Inc., New York, N.Y., 1988.

[14] Easley, J.T., and McFarland, D.E., "Buckling of Light-Gage Corrugated Metal Shear Diaphragms", Journal of the Structural Division, ASCE, Vol. 95, pp. 1497-1516, 1969.

[15] Abbas HH., Sause R. and Driver RG., "Shear Strength and Stability of High Performance Steel Corrugated Web Girders", In, SSRC conference, pp. 361-87, 2002.

[16] Elgaaly, M., Hamilton R.W. and Seshadri, A., "Shear Strength of Beams with Corrugated Webs", Journal of Structural Engineering, Vol. 122(4), pp. 390-398, 1996.

[17] Lindner, J. and Aschinger, R., "Grenzschubtragfähigkeit Von Iträgern mit Trapezförmig Profilierten Stegen", Stahlbau, Vol. 57(12), pp. 377-380, 1988.

[18] Real E, Bedynek A, Mirambell E. Numerical and experimental research in tapered steel plate girders subject to shear. In: International colloquium on stability and ductility of steel structures, Rio de Janeiro, Brazil; 2010. p. 747-54.

[19] Bergfelt, A. and Leiva, L., "Shear Buckling of Trapezoidally Corrugated Girders Webs", Report part 2, Pibl.SS4:2, Sweden, Chalmers University of Technology, 1984.

[20] Yi, J., Gil, H., Youm, K. and Lee, H., "Interactive Shear Buckling Behavior of Trapezoidally Corrugated steel webs", Engineering structures, Vol. 30, pp. 1659-1666, 2008.

[21] El-Metwally, A.S., "Prestressed Composite Girders with Corrugated Webs", M. Sc. thesis, Department of Civil Engineering, University of Calgary, Calgary, Alberta, Canada, 1998.

[22] Sayed-Ahmed, E.Y., "Behaviour of Steel and/or Composite Girders with Corrugated Steel Webs", Canadian Journal of Civil Engineering, Vol. 28, No. 4, pp. 656-672, 2001.

[23] Shiratoni, H., Ikeda, H., Imai, Y. and Kano, K., "Flexural Shear Behavior of Composite Bridge Girder with Corrugated Steel Webs around Middle Support", JSCE Journal, 724 (I-62), pp. 49-67, 2003. Hassanein, M.F. and Kharoob O.F., "Behavior of Bridge Girders with Corrugated Webs: (I) Real Boundary Conditions at the Juncture of the Web and Flanges", Engineering Structures, Vol. 57, pp. 554-564, 2013.

[25] Eurocode 3, "Design of Steel Structures- Part 1.1: General Rules and Rules for Buildings", ENV 1993-1-1, CEN, 2004. 